\title{
A Case of Pulmonary Metastatic Thyroid Cancer Complicated with Graves' Disease.
}

\author{
KATSUNORI SUZUKI, OsAmU NAKAGAWA AND Yoshifusa AIZAWA
}

First Department of Internal Medicine, Niigata University School of Medicine, Niigata 951-8510, Japan

\begin{abstract}
We report a case of pulmonary metastatic thyroid carcinoma complicated with Graves' disease. A 56year-old Japanese woman was referred to the Niigata Cancer Center Hospital for isotope therapy for pulmonary metastatic thyroid carcinoma. In 1993, she received a left-hemithyroidectomy. In 1999, the remnant thyroid was resected for isotope therapy of metastatic lesions in the lungs. Although she had been receiving suppressive therapy with levothyroxine, her general condition was good, and TRAb was positive before the operation. After a total thyroidectomy, the patient became thyrotoxic. For functioning metastatic lesions, the patient was treated with 5550 $\mathrm{MBq}$ of ${ }^{131} \mathrm{I}$ and methimazole. Thyroid function was normalized after the therapy but TRAb and TSAb levels remained high.
\end{abstract}

Keywords: Graves' disease, Thyroid cancer, Pulmonary metastasis, ${ }^{131} \mathrm{I}$.

(Endocrine Journal 48: 175-179, 2001)

Thyroid cancer occurs concomitantly in Graves' disease with a frequency of 5-10\% [1-3]. However, there are few reports of metastatic cancer leading to thyrotoxicosis. We describe herein a patient with pulmonary metastatic thyroid follicular carcinoma complicated with hyperthyroidism showing a significant increase of TSH receptor antibodies (TRAb) and TSH receptor-stimulating antibodies (TSAb) despite total thyroidectomy.

\section{Case report}

A 56-year-old Japanese woman was diagnosed with a thyroid nodule in April 1991. She was in euthyroid state when she visited a local hospital. Needle aspiration of the thyroid nodule showed no malignancy but chest $\mathrm{X}$-ray revealed bilateral nodu-

Received: July 21, 2000

Accepted: December 27, 2000

Correspondence to: Dr. Katsunori SUZUKI, First Department of Internal Medicine, Niigata University School of Medicine, 1-754 Asahimachi, Niigata 951-8510 JAPAN lar shadows. A left hemithyroidectomy was performed in April 1993 (histologic specifics and the reason why total thyroidectomy was not undertaken were not included in the letter of introduction) and she was placed on suppressive therapy with levothyroxine $(150 \mu \mathrm{g} /$ day $)$. Her general condition was good when she was first referred to our hospital on Nov. 25, 1999, for isotope therapy of pulmonary metastatic lesions. At this time she did not manifest hyperthyroidism and was healthy.

Serum levels of TSH, free $T_{4}$, and free $T_{3}$ under administration of $150 \mu \mathrm{g}$ levothyroxine were 0.01 $\mu \mathrm{IU} / \mathrm{ml}(\mathrm{N}: 0.35-4.94), 2.15 \mathrm{ng} / \mathrm{ml}(\mathrm{N}: 0.71-1.48)$, and $5.72 \mathrm{pg} / \mathrm{ml}(\mathrm{N}: 1.71-3.71)$, respectively. Thyroid echography revealed normal size and echogenecity of the remnant thyroid. Computed tomography (CT) of the neck-chest demonstrated only multiple pulmonary metastatic nodules (Fig. 1). For definite diagnosis, fine-needle aspiration of a pulmonary nodule guided by chest CT scan was done that revealed follicular thyroid carcinoma (Fig. 2). For isotope therapy, the remnant thyroid was resected at her previous hospital on Jan. 5, 2000 and was found to be normal thyroid tissue. Levothyroxine was dis- 


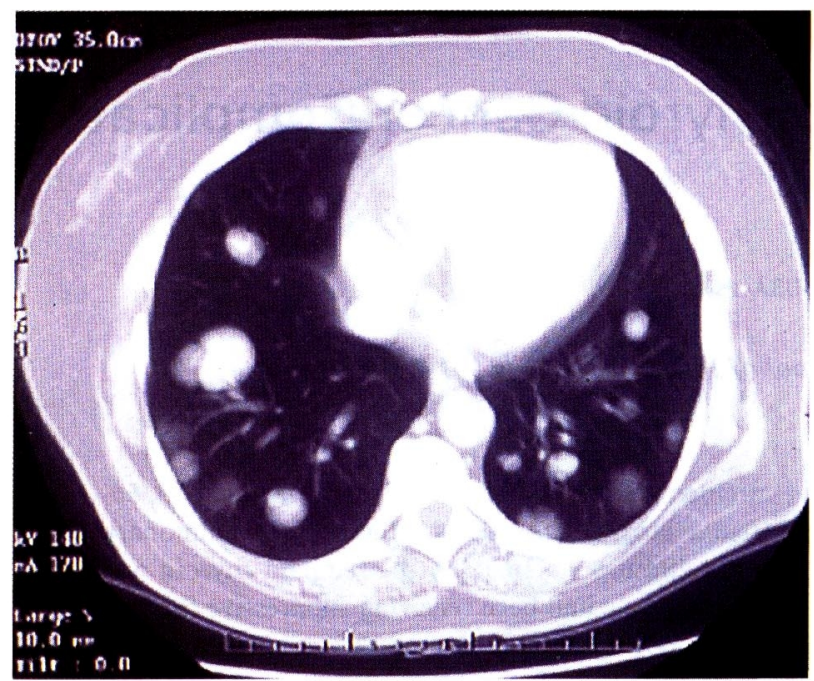

Fig. 1. Computed tomography (CT) of the chest. This demonstrated multiple pulmonary metastatic nodules. The mediastinal and other lymph nodes were not enlarged.

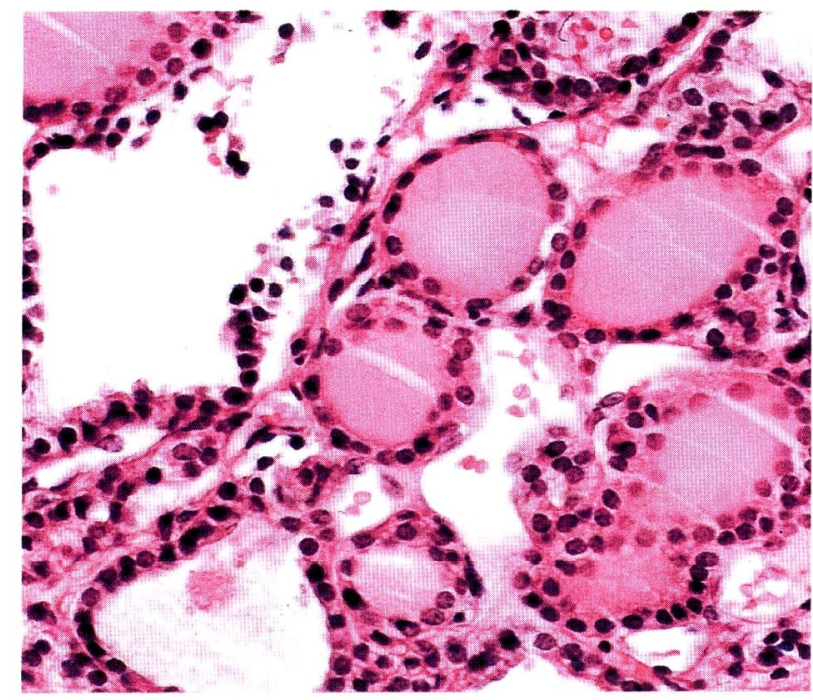

Fig. 2. Histological section of the pulumonary tumor $(20 \times)$. The cells are cuboidal, with large nuclei, arranged around follicles that contain dense colloids.

Table 1. Laboratory data ad admission

\begin{tabular}{|c|c|c|c|c|c|}
\hline WBC & $3400 / \mu 1$ & GOT & $125 \mathrm{IU} / 1$ & TSH & $<0.0 \mu \mathrm{IU} / \mathrm{ml}$ \\
\hline Seg & $71.0 \%$ & GPT & $215 \mathrm{IU} / 1$ & $\mathrm{~F}-\mathrm{T}_{3}$ & $21.29 \mathrm{pg} / \mathrm{ml}$ \\
\hline Lym & $22.0 \%$ & LDH & $197 \mathrm{IU} / 1$ & F-T $T_{4}$ & $6.00 \mathrm{ng} / \mathrm{dl}$ \\
\hline Mon & $5.0 \%$ & LAP & 73 IU/1 & $\mathrm{Tg}$ & $1430 \mathrm{ng} / \mathrm{ml}$ \\
\hline Eos & $1.0 \%$ & ALP & $233 \mathrm{IU} / 1$ & TRAb & $37.5 \%$ \\
\hline Bas & $1.0 \%$ & T-Bil & $0.8 \mathrm{mg} / \mathrm{dl}$ & $\mathrm{Tg}-\mathrm{Ab}$ & $<0.3 \mathrm{mg} / \mathrm{ml}$ \\
\hline $\mathrm{RBC}$ & $380 \times 10^{4} / \mu 1$ & $\gamma$-GTP & $64 \mathrm{IU} / 1$ & TPO-Ab & $<0.3 \mathrm{mg} / \mathrm{ml}$ \\
\hline $\mathrm{Hb}$ & $11.4 \mathrm{~g} / \mathrm{d} 1$ & $\mathrm{Ca}$ & $9.6 \mathrm{mg} / \mathrm{dl}$ & $\mathrm{TSAb}$ & $333 \%$ \\
\hline $\mathrm{Ht}$ & $35.1 \%$ & $\mathbf{P}$ & $4.1 \mathrm{mg} / \mathrm{dl}$ & & \\
\hline \multirow[t]{2}{*}{ Plt } & $14.3 \times 10^{4} / \mu 1$ & TP & $6.6 \mathrm{~g} / \mathrm{dl}$ & \multicolumn{2}{|c|}{ BGA (3L nasal cannula) } \\
\hline & & $\mathrm{Na}$ & $141 \mathrm{mEq} / 1$ & $\mathrm{pH}$ & 7.415 \\
\hline CRP & $0.1 \mathrm{mg} / \mathrm{dl}$ & $\mathrm{K}$ & $3.9 \mathrm{mEq} / 1$ & $\mathrm{PCO}_{2}$ & $36.9 \mathrm{mmHg}$ \\
\hline \multirow[t]{2}{*}{ ESR } & $14 \mathrm{~mm} 1 \mathrm{~h}$ & $\mathrm{Cl}$ & $107 \mathrm{mEq} / 1$ & $\mathrm{PO}_{2}$ & $80.1 \mathrm{mmHg}$ \\
\hline & $34 \mathrm{~mm} 2 \mathrm{~h}$ & $\mathrm{Cr}$ & $0.3 \mathrm{mg} / \mathrm{dl}$ & $\mathrm{HCO}_{3}$ & $23.1 \mathrm{mmol} / \mathrm{L}$ \\
\hline CEA & $7.77 \mathrm{ng} / \mathrm{ml}$ & BUN & $19 \mathrm{mg} / \mathrm{dl}$ & $\mathrm{BE}$ & $-1.1 \mathrm{mmol} / \mathrm{L}$ \\
\hline CA19-9 & $43.94 \mathrm{U} / \mathrm{ml}$ & UA & $5.1 \mathrm{mg} / \mathrm{dl}$ & $\mathrm{SaO}_{2}$ & $98.1 \%$ \\
\hline \multirow[t]{4}{*}{ Calcitonin } & $25.3 \mathrm{pg} / \mathrm{ml}$ & PBS & $129 \mathrm{mg} / \mathrm{dl}$ & & \\
\hline & & $\mathrm{TC}$ & $130 \mathrm{mg} / \mathrm{dl}$ & & \\
\hline & & TG & $66 \mathrm{mg} / \mathrm{dl}$ & & \\
\hline & & HDL-C & $28 \mathrm{mg} / \mathrm{dl}$ & & \\
\hline
\end{tabular}

continued after the operation, but her condition took a gradual change for the worse. She complained of dyspnea and presented symptoms suggesting thyroid hyperfunction (restlessness, insomnia, tremor, and 5 $\mathrm{kg}$ weight loss). She was transferred to our hospital for isotope therapy on Jan. 25, 2000.

Physical examination on admission revealed that she was $149.2 \mathrm{~cm}$ in height and $52.5 \mathrm{Kg}$ in weight $\left(\mathrm{BMI}=23.6 \mathrm{Kg} / \mathrm{m}^{2}\right)$. Blood pressure was $94 / 54$ $\mathrm{mmHg}$, and pulse rate was $120 \mathrm{bpm}$ and regular. 


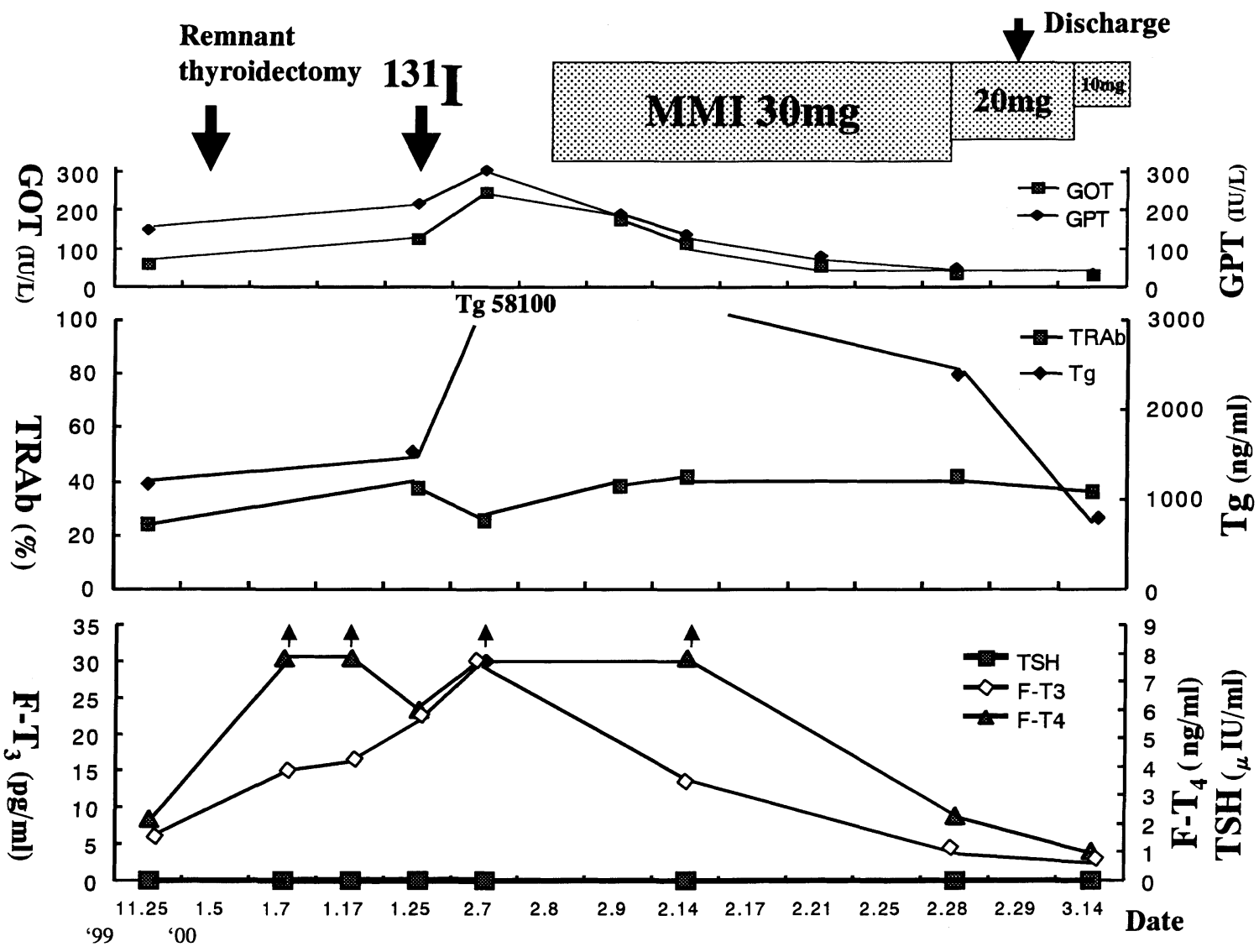

Fig. 3. The clinical course after admission: upper berth: change of transaminases; middle berth: change of TRAb and thyroglobulin; lower berth: change of $\mathrm{TSH}_{1} \mathrm{FT}_{3}$ and $\mathrm{FT}_{4}$. ${ }^{131} \mathrm{I}$ : 131-iodine therapy. MMI: methimazole.

There were no palpable thyroid gland or neck lymph nodes. No ophthalmopathy was present. Areflexia of the Achilles tendon was noted. She complained of palpitation, dyspnea, and tremor.

Thyroid function test on admission showed elevated free $\mathrm{T}_{4}$ and free $\mathrm{T}_{3}$ and suppressed TSH. TRAb (N: 15\%) and TSAb (N: 180\%) were positive (Table 1). Other routine biochemical tests were normal except for mild elevations of GOT and GPT levels (Table 1). The first operative specimen from the previous hospital in 1993 was re-evaluated by two pathologists of our hospital. It showed typical collision of papillary carcinoma and invasive-follicular adenoma as evidenced by nuclear grooving and intranuclear inclusion.

Despite total thyroidectomy, the patient remained in a hyperthyroid state with elevated serum levels of free $T_{3}$ and $T_{4}$ and suppressed TSH (Fig. 3). The patient was then treated with $5550 \mathrm{MBq}$ of ${ }^{131} \mathrm{I}$. Two weeks later, radioiodine uptake was observed in the diffused pulmonary metastatic lesions (Fig. 4). Serum concentrations of free $T_{4}$ and free $T_{3}$ were elevated beyond the measurable range, and serum thyroglobulin level was $58,100 \mathrm{ng} / \mathrm{ml}$ (normally, 60 $\mathrm{ng} / \mathrm{ml}$ ). Serum levels of both GOT and GPT were more than $300 \mathrm{IU} / \mathrm{L}$. There was no radioiodine uptake over the thyroid bed, but scans revealed massive uptake of diffuse pulmonary metastasis (Fig. 4). Whole-body scans were normal. She became sicker, and methimazole and propanolol were prescribed. Ten days later, her condition stabilized, and she was discharged from our hospital on March 4, 2000. Two weeks later, serum thyroglobulin concentration showed a marked decrease, and liver and thyroid functions returned to normal, while TRAb and TSAb remained positive at $33.1 \%$ and $962 \%$, respectively. The pulmonary metastatic lesions demonstrated a marked reduction in size after isotope therapy. 


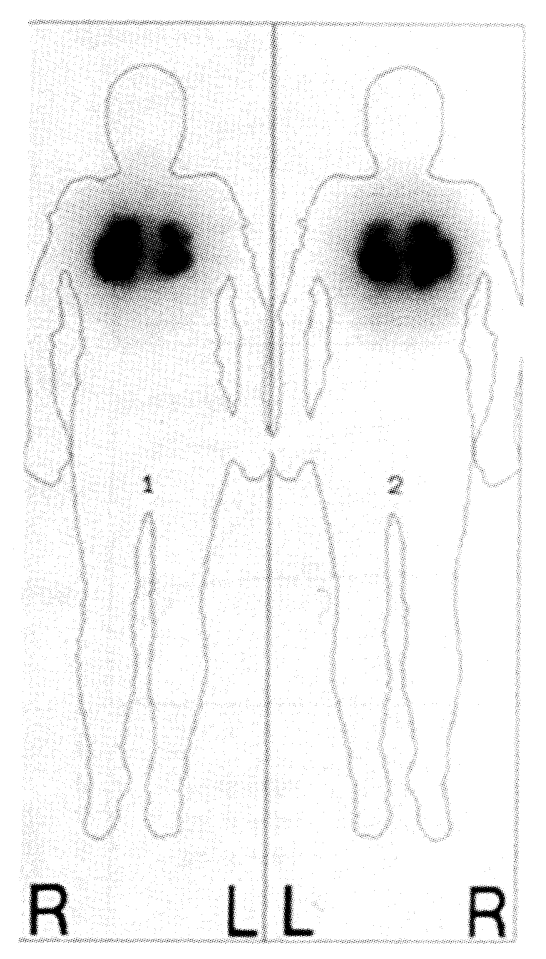

Fig. 4. ${ }^{131}$ I scintigraphy performed thirteen days after 5550 MBq sodium 131-iodine therapy. There was a massive uptake of the tracer in diffuse pulmonary metastases while none occurred over the thyroid bed.

\section{Discussion}

We have described herein a patient with pulmonary metastasis of thyroid cancer who showed hyperthyroidism despite total thyroidectomy. Thyroid tumors associated with hyperthyroidism occur under three conditions. The first is that of Graves' disease complicated with thyroid carcinoma, although the incidence of thyroid carcinoma in Graves' disease is still controversial [1-5]. The second is that in which hyperthyroidism is due to oversecretion of the thyroid hormone from thyroid carcinoma or metastatic lesions, wherein radioiodine uptake can be demonstrated in thyroid carcinoma or in metastatic lesions $[5,7]$. Nevertheless, oversecretion of thyroid hormones from metastatic lesions has rarely been proven. The third is that in which primary thyroid carcinomas or other metastatic carcinomas rapidly and directly invade normal thyroid tissue. A large quantity of the thyroid hormone is released from normal thyroid tissue infiltrated by carcinoma and manifest thyrotoxicosis. In these cases, patients eventually develop hypothyroidism. It is said that some patients manifest thyrotoxicosis in the case of a rapidly progressive malignant tumor. Cases of invasion by malignant lymphoma and pancreatic carcinoma have been reported to occur in hyperthyroidism [8-10].

Although the present patient belongs to the second type of hyperthyroidism, interestingly the stimulating antibodies were high. Since there is no previous report of thyrotoxicosis due to stimulation of pulmonary metastatic lesions by TSAb, this patient is the first such reported case.

In regard to the mechanism for the oversecretion of thyroid hormones in pulmonary metastatic carcinoma, one could hypothesize as follows. 1) TSAb may have stimulated the metastatic carcinoma to develop thyrotoxicosis in the patient. Development of Graves' disease has been described following parathyroidectomy [11], radioiodine therapy [12], acute and subacute thyroiditis [13] and in patients treated with a percutaneous ethanol injection (PEI) [14]. Before the remnant thyroidectomy at the previous hospital, TRAb was positive and remained stable after the operation. Although spontaneous development of Graves' disease cannot be excluded, the time sequence and the negative familial and personal history for autoimmune diseases suggest a possible connection between the two phenomena. The remnant thyroidectomy may have triggered an autoimmune response sensitizing the antibodies that would stimulate the cancer cells leading to thyrotoxicosis. This speculation is supported by the finding that the resected remnant thyroid was found to be of normal thyroid tissue and did not reveal histologic appearance of Graves disease. 2) The antibodies could have been functioning as bystanders while the carcinoma was producing the thyroid hormone itself. This hypothesis is supported by the finding that TRAb and TSAb did not show remarkable change. The exact mechanisms in the present case have not been elucidated and further study is required. Incidentally, exacerbation of thyrotoxicosis after administration of ${ }^{131}$ I may be responsible for the destruction of thyroid cells in lung metastasis by radioiodine as previously reported [12].

We described here for the first time that hyperthyroidism induced by pulmonary metastatic carcinoma may occur after remnant thyroidectomy even 
present.

\section{References}

1. Shapiro SJ, Friedman NB, Perzik SL, Catz B (1970) Incidence of thyroid carcinoma in Graves' disease. Cancer 26: 1261-1270.

2. Farbota LM, Calandra DB, Lawrence AM, Palyoyan E (1985) Thyroid carcinoma in Graves' disease. Surgery 98: 1148-1152.

3. DeGroot LJ, Larsen PR, Refetoff S, Stanbury JB (1984) The thyroid and its diseases. 5th ed. New York: John Wiley: 756-831.

4. Behar R, Arganini M, Wu TC, McCormick M, Strauss FH, De Groot LJ (1986) Graves' disease and thyroid cancer. Surgery 100: 1121-1127.

5. Hales IB, McElduff, Crummer P (1992) Does Graves' disease or thyrotoxicosis affect the prognosis of thyroid cancer? J Clin Endocrinol Metab 75: 886-889.

6. Onai T, Takahashi K, Okada S, Ohshima K, Shoda J, Maruta S, Mori M, Shimomura Y, Kobayashi I, Kobayashi S (1987) A case of pulmonary and bone metastatic thyroid cancer that presented with hyperthyroidism. Japanese title of journal Hormone and Clinic 35: 92-94 (in Japanese).

7. Kobayashi K, Miyakawa S, Iida H (1983) A case of thyroid carcinoma metastatic lesion which synthesized and secreted thyroid hormone. Hormone and Clinic. 31: 85-87 (in Japanese).

8. Eriksson M, Ajmani SK, Mallette LE (1977) Hyperthyroidism from thyroid metastasis of pancreatic adenocarcinoma. JAMA 238 (12): 1276-1278.

9. Shimaoka K, VanHerle AJ, Dindogru A (1976) Thyrotoxicosis secondary to involvement of the thyroid with malignant lymphoma. J Clin Endocrinol Metab 43: 64-68.

10. Samuels MH, Launder T (1998) Hyperthyroidism due to lymphoma involving the thyroid gland in a patient with acquired immunodeficiency syndrome: case report and review of the literature. Thyroid 8: 673677.

11. Walfish PG, Caplan D, Rosen ID (1992) Post-parathyroidectomy transient thyrotoxicosis. J Clin Endocrinol Metab 75: 224-227.

12. Regalbuto C, Salamone S, Scollo C, Vigneri R, Pezzino V (1999) Appearance of anti TSH-receptor antibodies and clinical Graves' disease after radiation therapy for hyperfunctioning thyroid adenoma. $J$ Endocrinol Invest 22: 147-150.

13. Werner SC (1979) Graves' disease following acute (subacute) thyroiditis. Arch Intern Med 139: 13131315.

14. Monzani F, Caraccio N, Goletti O, Lippolis PV, Casolaro A, Del Guerra P, Cavina E, Miccoli P (1997) Five-year follow-up of percutaneous ethanol injection for the treatment of hyperfunctioning thyroid nodule: a study of 117 patients. Clin Endocrinol 46: 9-15. 